Maria Arkhipova

Sergeev Institute of Environmental Geoscience RAS (IEG RAS); Ulansky pereulok 13, building 2, P.O. Box 145 101000, Moscow, Russia;

Tel. +7 495 6247257, e-mail: masha-a@yandex.ru

\title{
ON THE CENTRAL RUSSIAN UPLAND: HISTORICAL PERSPECTIVE
}

ABSTRACT. We studied the change of forestland in the Central Russian Upland within the deciduous forest, forest-steppe, and steppe zones using old maps (XVIII$X X$ cc.) and current satellite images. The forest distribution within the Central Russian Upland has been relatively stable during the last 220 years. On average, the decrease in the forested area was small. However, we identified significant changes in certain regions. In the southern part of $C R U$, the significant increase of the forested land is caused by the forest protection of abatis woodland and afforestation. During the last 100 years, reforestation took place mainly in the Oka basin due to both afforestation and natural reforestation. New forests appeared generally in ravines within all zones. The analysis of the abatis forests changes from the XVIII to XX cc. allowed us to identify forested area within the Central Russian Upland prior to active development.

KEY WORDS: forestland, forest dynamic, Central Russian Upland, human impact

\section{INTRODUCTION}

The aim of this research is to study changes of forest distribution in the Central Russian Upland and to identify human impact on forests. Analysis of old maps and satellite images indicates that there has been change of forestland during the last 220 years and makes it possible to calculate the rate of deforestation and reforestation and to estimate the role of forest protection and afforestation in forest distribution on the Central Russian Upland. In our study, we specifically focused on changes (cutting) of the abatis forests over the last 200 years. Large forests were transformed to agricultural fields with coppices. Now, these forests are not distinguishable from the adjacent lands. We considered these processes in the estimate of the rate of the forested land change and modeled the percentage of the forested land at the end of the XVI C.

The Central Russian Upland is situated in the centre of the East European Plain. It spreads from the Oka River in the north to the Donetsk Ridge in the south. The Kalachskaya Upland is the south-east part of the Central Russian Upland. The northern part of the upland is composed of Dnepr moraine that is covered with silt. In the southern part, Pre-Quaternary deposits are overlaid with silt [Spiridonov, 1978]. The Central Russian Upland was the refugium for deciduous broad-leaved forests during the glacial periods. The territory has temperate continental climate, good for forests. Average annual temperature is $+3^{\circ}$ to $+7^{\circ}$, annual precipitation amount is 346 to $644 \mathrm{~mm}$, and the sum of active temperatures is 1848 to $2934^{\circ}$. Three phytogeographical zones change each other from the north to the south of the Upland: the zone of deciduous broad-leaved forests, foreststeppe zone, and steppe zone [Ogureeva, 1999]. The chernozem soils dominate in the steppe and forest-steppe, and gray forest soil prevails in the deciduous broad-leaved forests zone. Based on the vegetation map of Russia [Bartalev et al., 2001], we estimated the percentage of the forested land for the entire Upland at 9\%; it is 14\% within the boundaries of deciduous broad-leaved forests zone and 5 

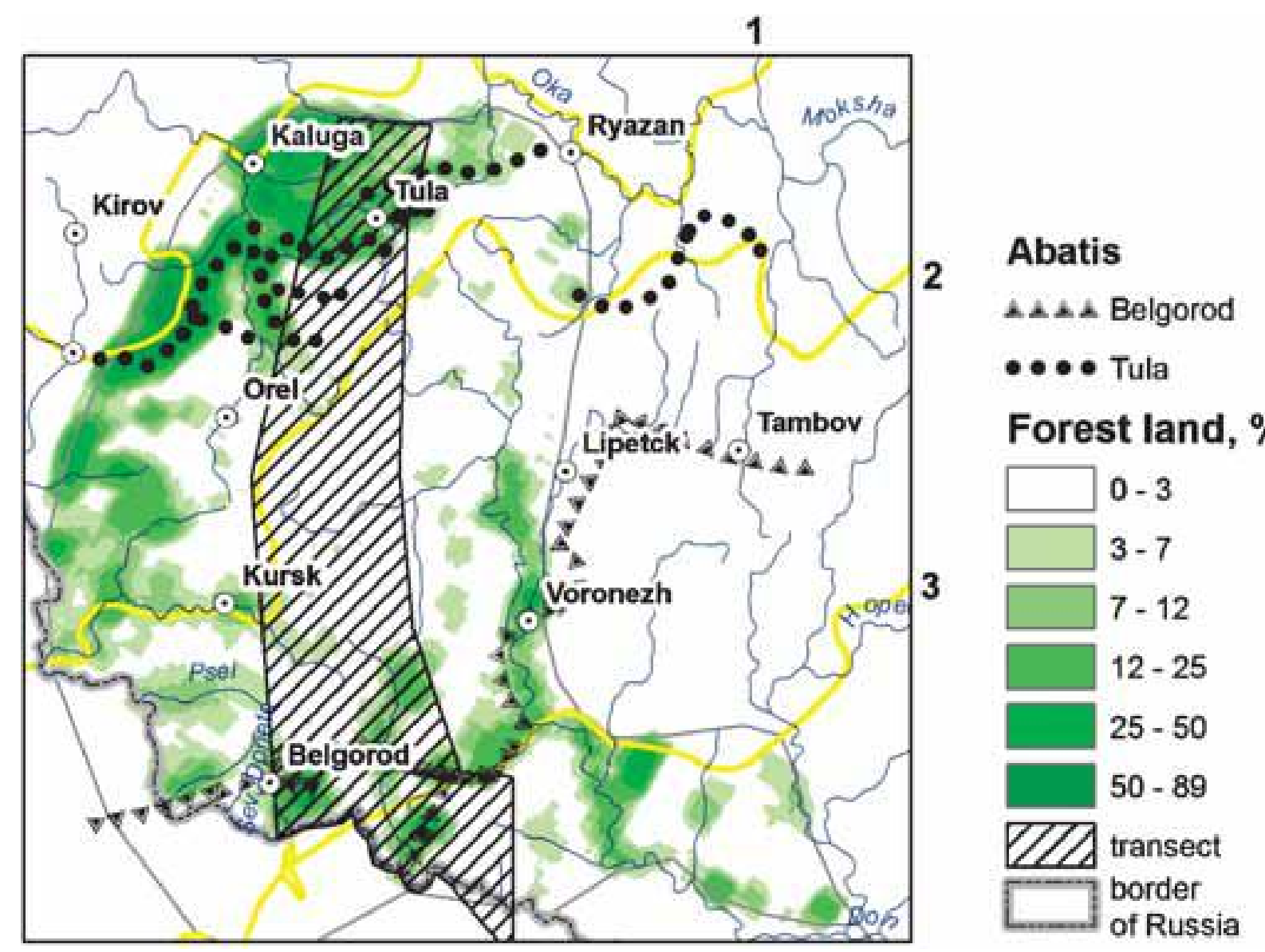

Fig. 1. The percentage of the forested land on the Central Russian Upland; the northern boundaries of the zones:

1 - deciduous broad-leaved forests, 2 -forest-steppe, 3 - steppe.

to $6 \%$ within the boundaries of forest-steppe and steppe zones (Fig. 1).

Special attention is given to the abatis forest areas [Zagorovskij, 1969, 1980; Jakovlev, 1916]. The Russian state grew from the north to the south. The abatises were created for the protection from tatar raids. They included engineering constructions and large forests as a natural obstacle for cavalry. The abatis forests were protected from cutting and were the first reserves by this way. They lost their importance when Russia conquered Crimea in the XVIII c. Then, part of the abatis forests continued to be protected as shipbuilding timber or manufactory forests, while another part was cut for agricultural fields.

\section{MATERIALS AND METHODS}

For the detailed analysis, we chose a transect with the width of about $100 \mathrm{~km}$ and the length of about $500 \mathrm{~km}$, going through the center of Upland from north (the Oka river) to south (the region of Belgorod and Valuiky). The transect crosses deciduous the broad-leaved forest zone in the north, foreststeppe zone in the center, and steppe zone in the south. The transect is divided into $10 \times 10 \mathrm{~km}$ cells. All parameters in our research are calculated for every cell.

We used winter satellite images Landsat (2000-2003) to estimate the current percentage of forested land. Non-forest, deciduous, and coniferous forests are clearly seen at these images. The standard supervised classification from Erdas was applied. To exclude tree vegetation in populated places (parks and gardens), we used the settlement vector layer from OpenStreetMap project (www.openstreetmap.org). We removed forest belts along fields and ravines by the Neighborhood functions from Erdas. The result of our work is the map of forests. Using this map, we calculated the percentage of 


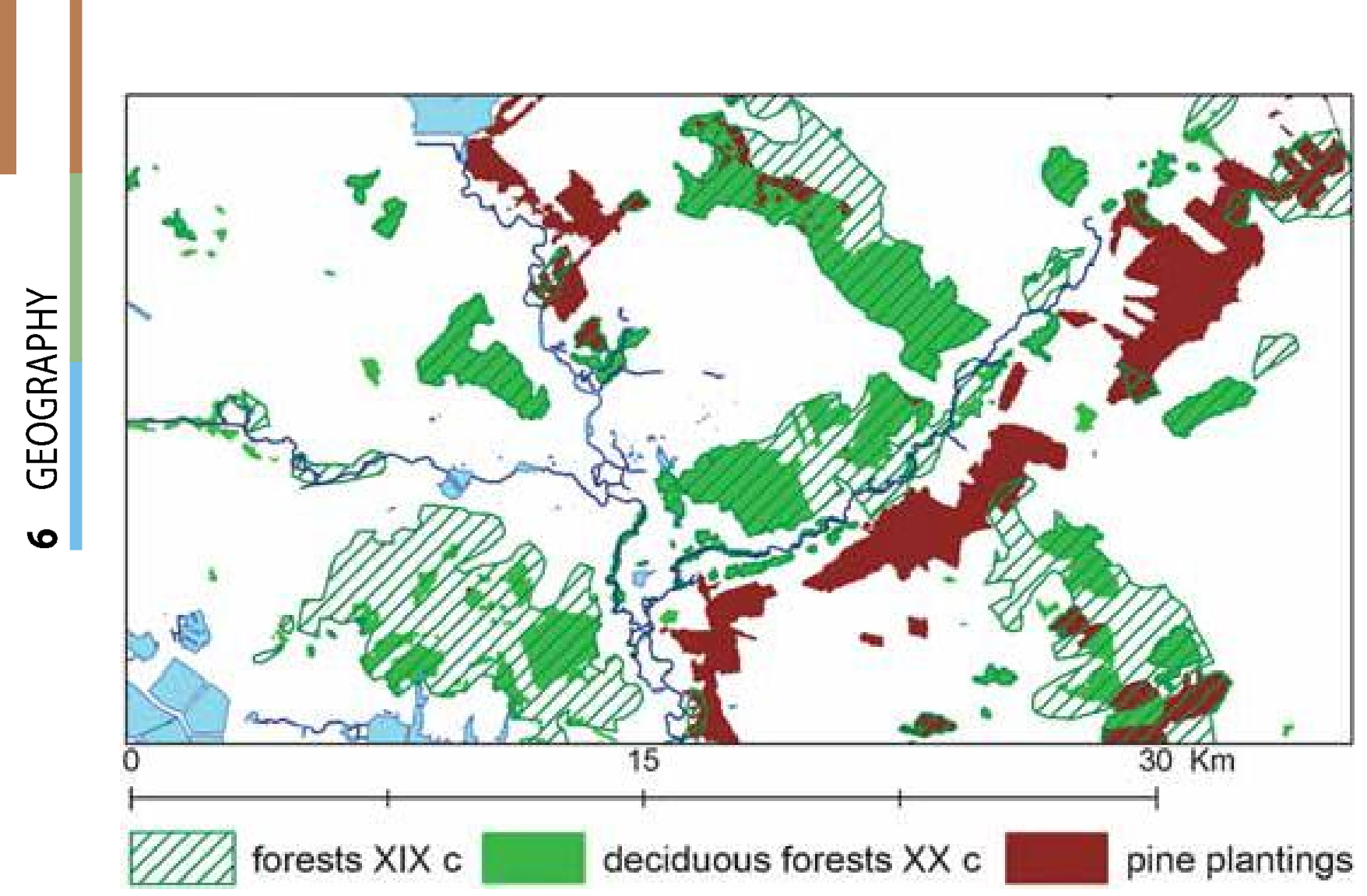

Fig. 2. The pine planted forests near Staryi Oskol.

forested land along the transect for each images and historical maps (1860-1880) grid.

[Strel'bitskii, 1868-1887] (Fig. 2). Using literature, satellite images, and historical The planted coniferous forests were maps the remnants of the abatis forests isolated by comparing the satellite are selected (Fig. 3).

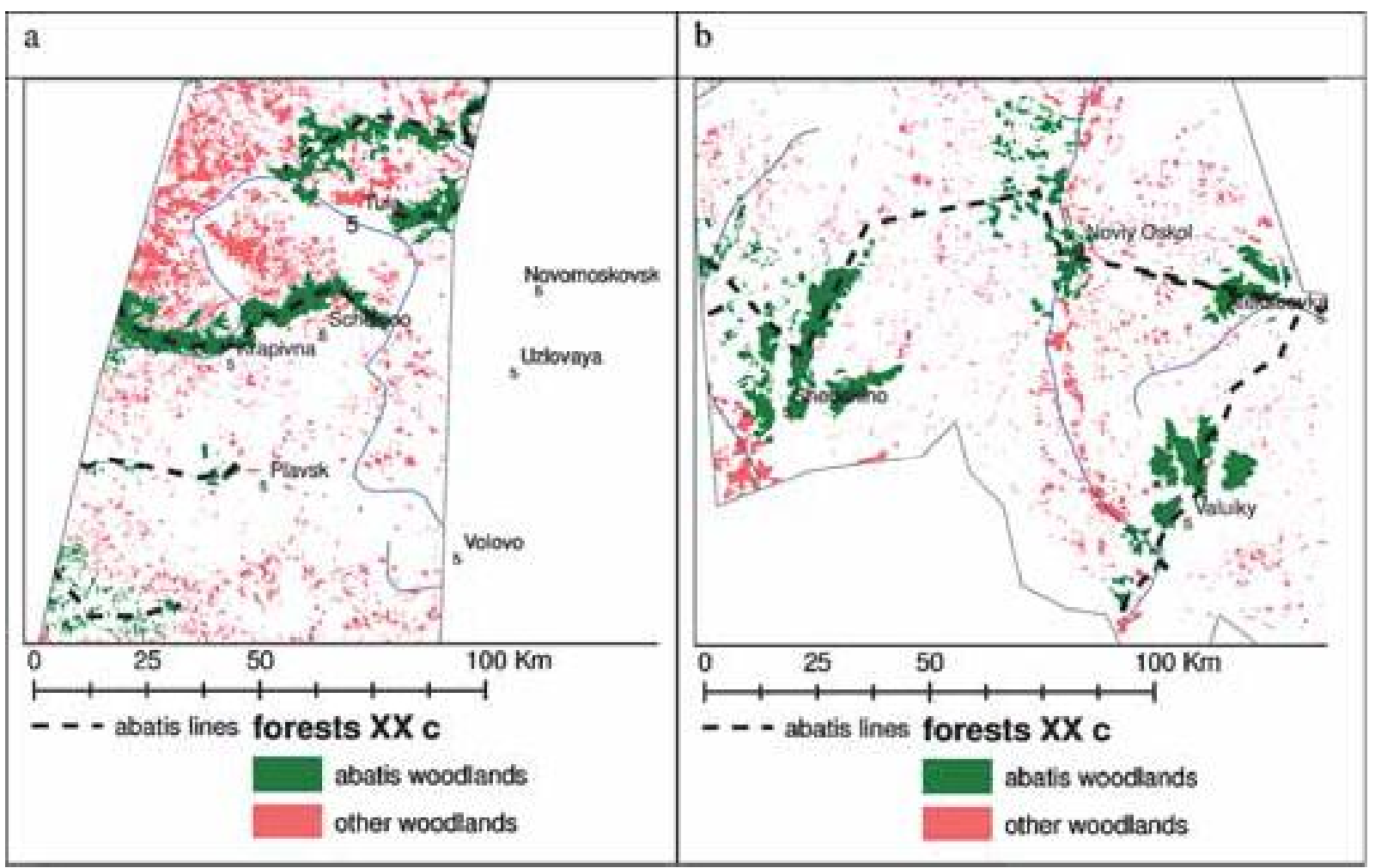

Fig. 3. The remnants of the abatis forests at the end of the XX c:

$a$ - Tula abatis, $b$ - Belgorod abatis. 
To calculate the percentage of the forested land at the end of the XVIII C., we used the land surveying maps for the end of the XIX c. [Plans-atlases... 1780] and military maps [Strel'bitskii, 1868-1887]. All cartographic and statistic processing was done in ArcGis and Excel.

\section{RESULTS}

Many researchers studied changes of the forested land percent cover of Central Russia. M.A. Tsvetkov [1957] studied the statistical data and has shown the decrease of the forested land percent cover in the center of European Russia from the XVII to the XX c.c. at $13 \%$, on average. The forested area decreased significantly in the central provinces within the deciduous broadleaved forests and forest-steppe zones. The most notable decrease occurred in densely populated provinces. Based on old maps and satellite images, I.V. Kuksa [1993] showed the increase of the forested land caused by agricultural activities decrease in the northern part of the Central Russian Upland. The same process is observed at the adjacent south-west Moscow region [Arkhipova, Zamesova, 2006]. The area of the forested land decreased by $5 \%$ in the southern part of the Central Russian Upland [Chendev, 2008; Belevancev, 2012].

The statistical data for provinces do not reflect the real situation, because the provinces may have different natural conditions. The key plots studies show different trends of forested area changes in the northern and southern parts of the Upland. That is why we used the continuous transect to determine the forest area dynamics and areas where forest cover changed.

According to the paleogeographic papers written by Ju.G. Chendev [2008], intensive deforestation of Central Russian Upland began about 400 years ago. Today, the forests are distributed on the Upland unevenly. Regions with high percentage of the forested land are in the north of the Upland: the basin of the river Zusha and the area at the contact belt between forest-steppe and steppe (the right banks of the rivers Korocha, Valuy, and Tihaya Sosna, and the basin of the river Oskol); other parts of the transect have low percentage of the forested land (4-7\%) within all phytogeographical zonal belts.

Large planted pine stands are situated mainly in the Oskol and Severskiy valleys and in the northern part of the Upland near the town of Aleksin (Fig. 4b). In the southern part of the Upland, coniferous afforestation is generally conducted in flood plains and on terraces, while in the northern part, it is done on watersheds. The coniferous planted stands are $6,5 \%$ of all forested lands within the transect. There are vast forested areas in the upper river Oskol due to man-made afforestation.

Forest preservation in the past also contributed to the uneven forest distribution along the transect. The former abatis forest areas are $32 \%$ of all forests within the transect. There are vast forested areas in the contact belt between forest-steppe and steppe due to forest preservation.

The maps of the forested area percentage are made with the help of old maps (the end of the XVIII C. to the end of the XIX c.) and satellite images (Fig. 5).

The percentage of forested area decreased by $6 \%$ during the last 220 years. Within the deciduous broad-leaved forest zone, the decrease took place in the XVIII-XIX c.C.; from the end of the XIX c. to the end of the $X X c_{c}$, the forested area slightly increased. At the same time, the intensive deforestation in forest-steppe zone occurred during the last 150 years. The percentage of forest area decreased from $13 \%$ till $8 \%$ (Table 1).

The uneven forest distribution along the transect did not change during the last 220 years. Forested area decreased mainly in the contact belt between foreststeppe and steppe. Here, the former abatis woodlands were cut. The forested land area decreased by 20\% (see Fig. 5). Less reduction of the forested land is observed 


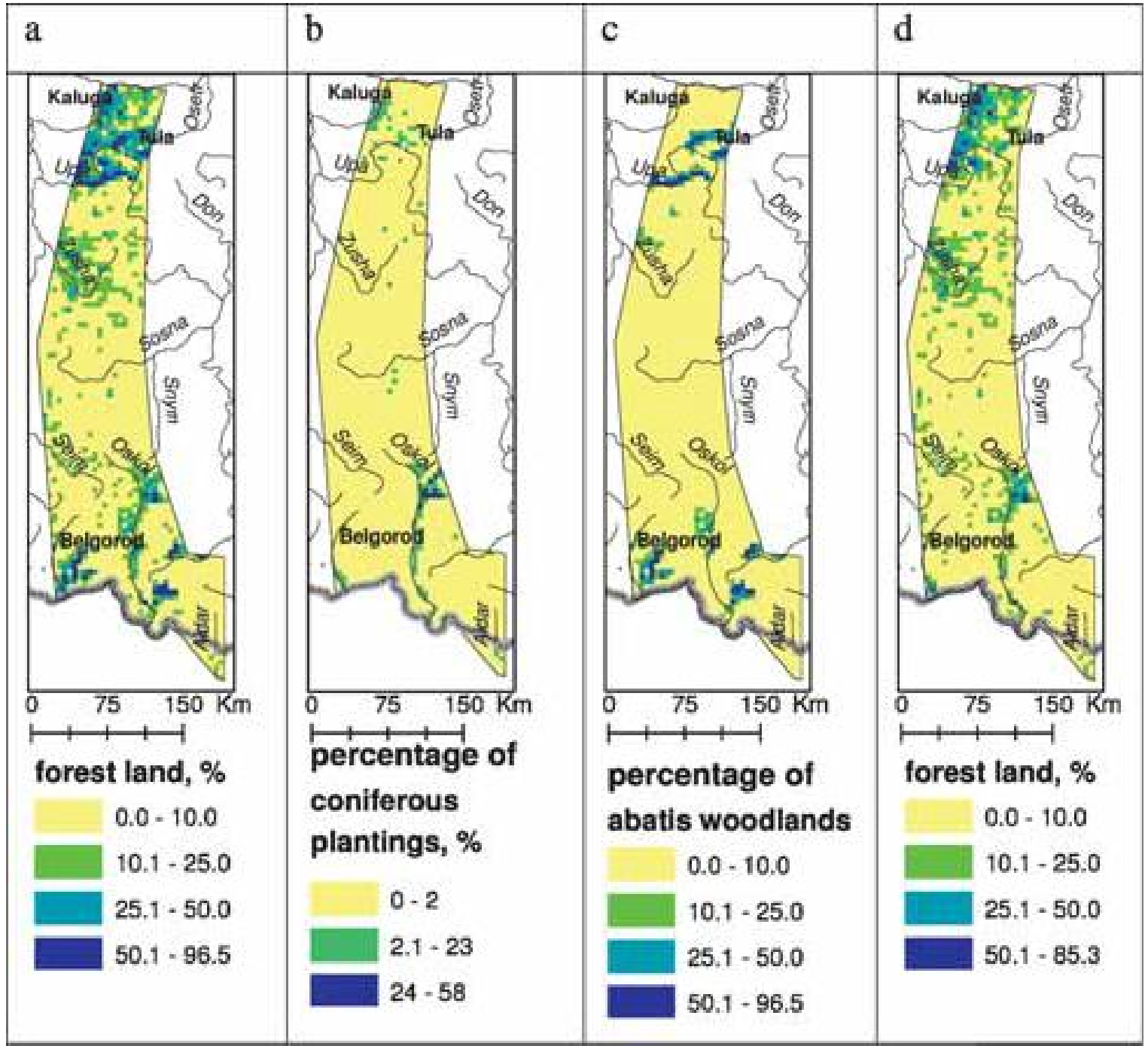

Fig. 4. The forested land distribution along the transect:

$a$ - current percentage of the forested land, $b$ - percentage of the coniferous planted stands, $c$ - percentage of the former abatis woodlands,

$d$ - percentage of the forested land without the coniferous planted stands and abatis woodlands.

in the basin of the rivers Upa and Zusha and in the region of the Tula abatis. At the rest part of the transect changes of the forested land are small.

The ability of forest to restore is an important characteristic of natural environments. Using the old maps (1860-1880) and modern satellite images we analyzed the rate of forest regeneration (Fig. 6).
Forest regeneration is going mainly in the north and north-west of the transect within the deciduous broad-leaved forest zone, most intensive in the river basin of Zusha. Fifteen percent of the new forests are coniferous planted stands. The deciduous forests appear mainly in ravines (Fig. 7).

The probable reason of forest regeneration is the reduction of agricultural land during the

Table 1. The percentage of forested area

\begin{tabular}{|l|c|c|c|}
\hline \multicolumn{1}{|c|}{ Phytogeographical zone } & End of the XVIII c. & End of the XIX c. & End of the XX c. \\
\hline The entire transect & $16.5 \%$ & $13.2 \%$ & $10.5 \%$ \\
Deciduous broad-leaved forest zone & $21.6 \%$ & $14.4 \%$ & $15.9 \%$ \\
Forest-steppe zone & $14 \%$ & $12.8 \%$ & $7.9 \%$ \\
\hline
\end{tabular}


a

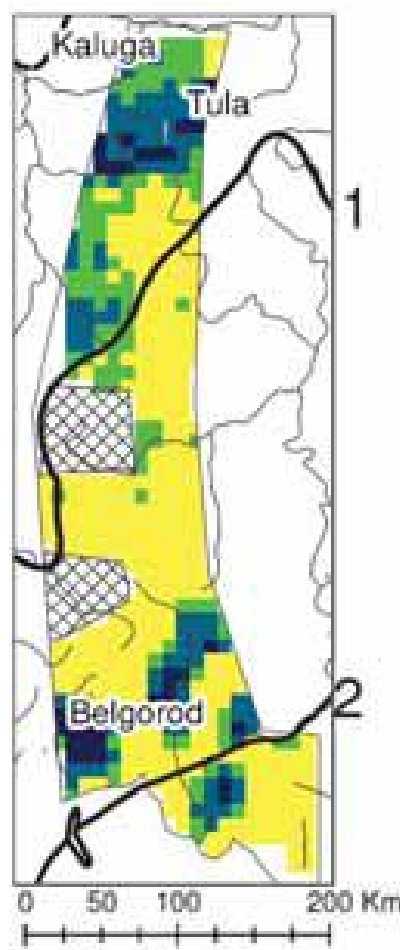

$18 \times 8$ data is absent

$\square 06-12 \mathrm{~s}$
$12.15-25 \mathrm{~s}$
$25.15 \mathrm{~s}-50 \mathrm{~N}$
$50.15-80.0 \mathrm{~S}$ b
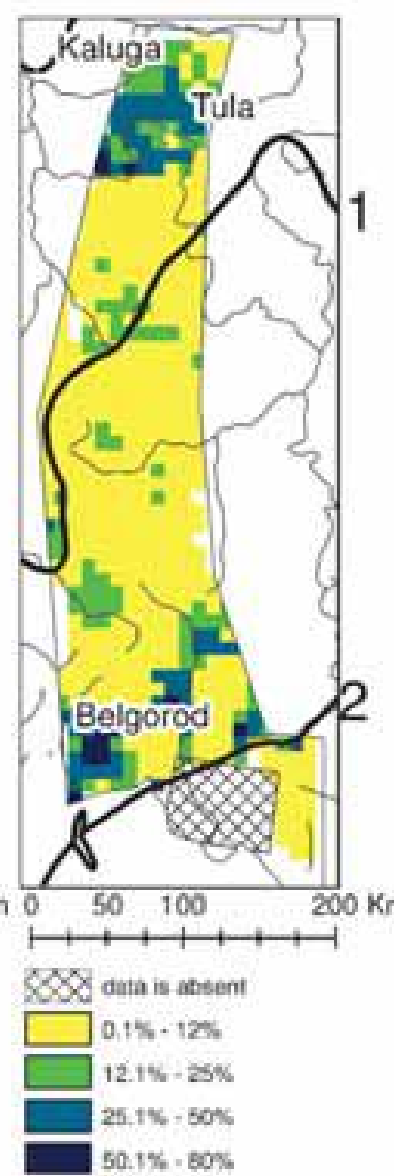

c
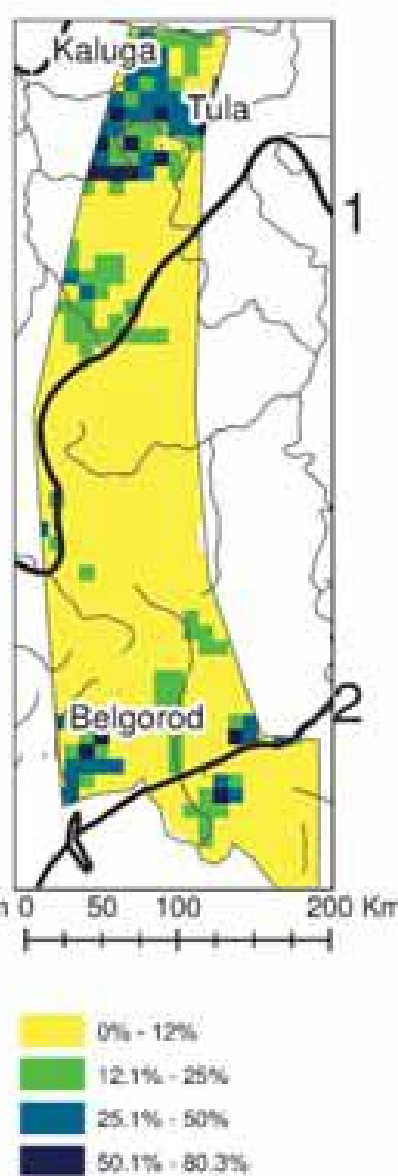

d

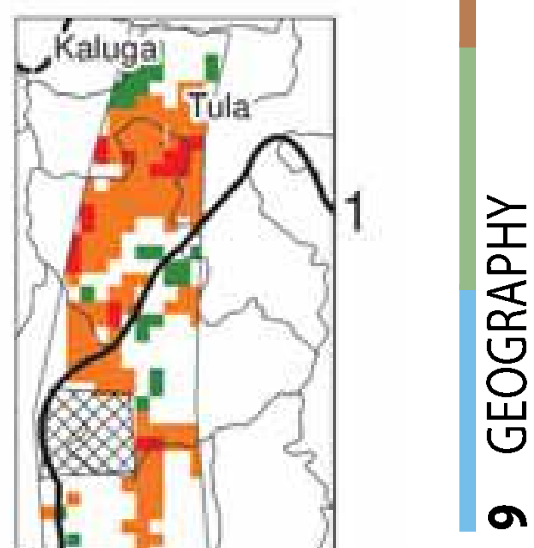

Fig. 5. The percentage of the forested area at the end of:

$a-X V I I I c ., b-X I X c ., c-X X$ c., $d$-change of the forested area percentage from the XVIII to the XX cc.

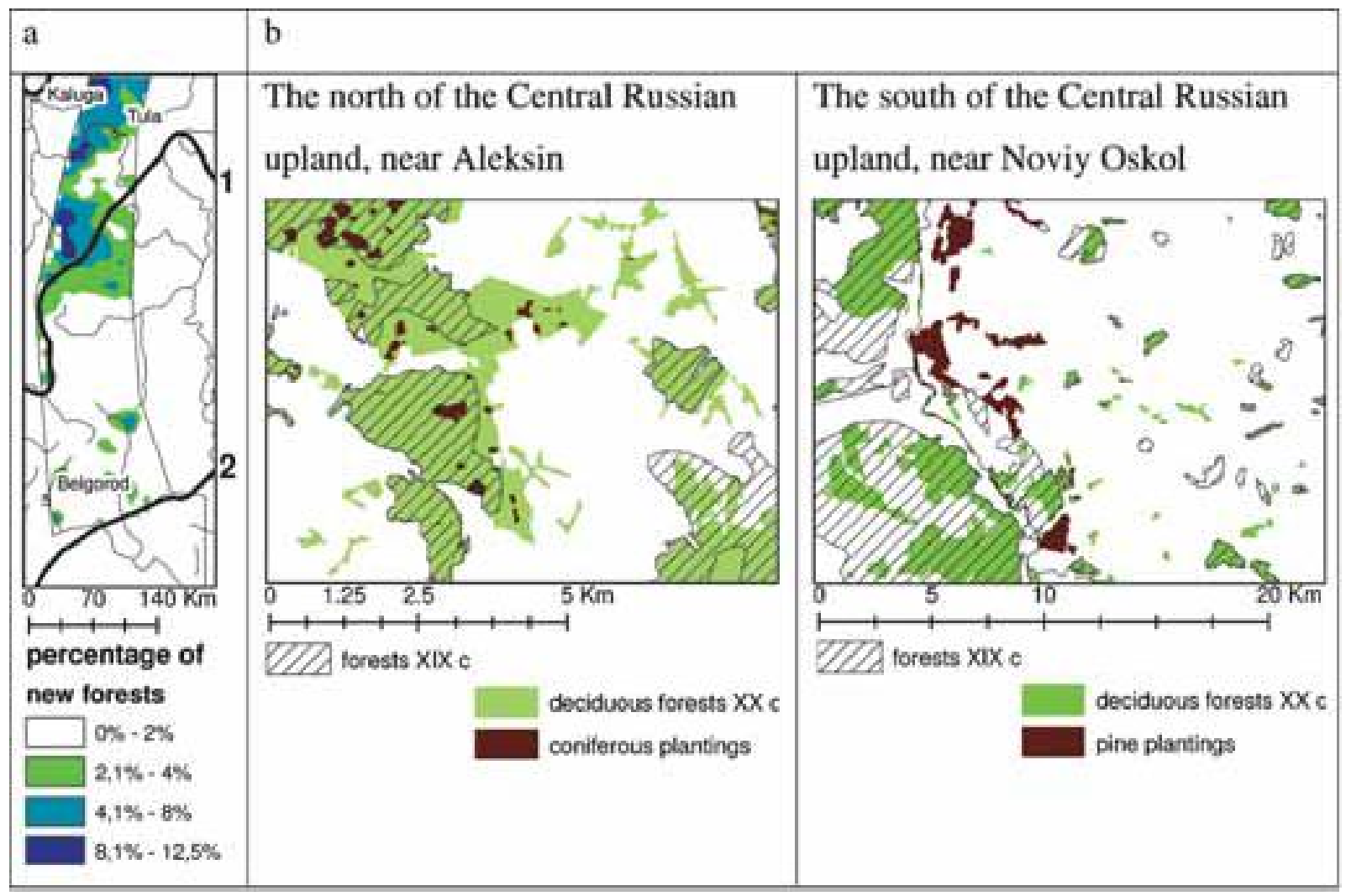

Fig. 6. Forest regeneration along the transect during last 140 years:

$a$ - the rate of the regeneration, $b$ - the examples of the regeneration. 


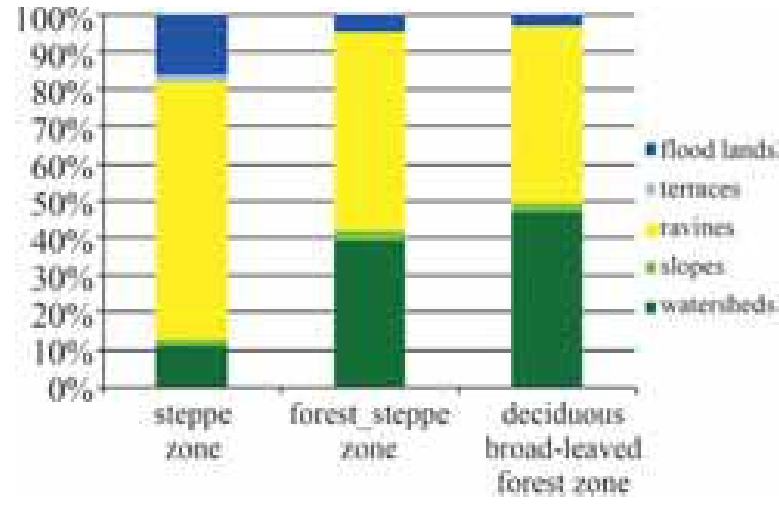

Fig. 7. The distribution of the new forests by the ecotops.

last 100 years. The system of reafforestation contributed to forested area increase also, particularly due to creation of erosionpreventive forest belts.

The data on the abatis woodlands dynamics during the last 220 years (Table 2) allow us to assess the forested area changes under active human impact.

Using these data, we estimated the percentage of the forested land change at the time of abatis creation. Many abatis woodlands after the end of the XVIII c. lost their protected status. Only small forests and coppices remained at the former abatis area, while in the past, the large woodlands were here. We interpolated the rate of the abatis woodlands change to the forests of the adjacent regions and made a model of forest distribution along the transect at the end of the XVI c. (Fig. 8).

According to the model, the forests were distributed evenly within the deciduous

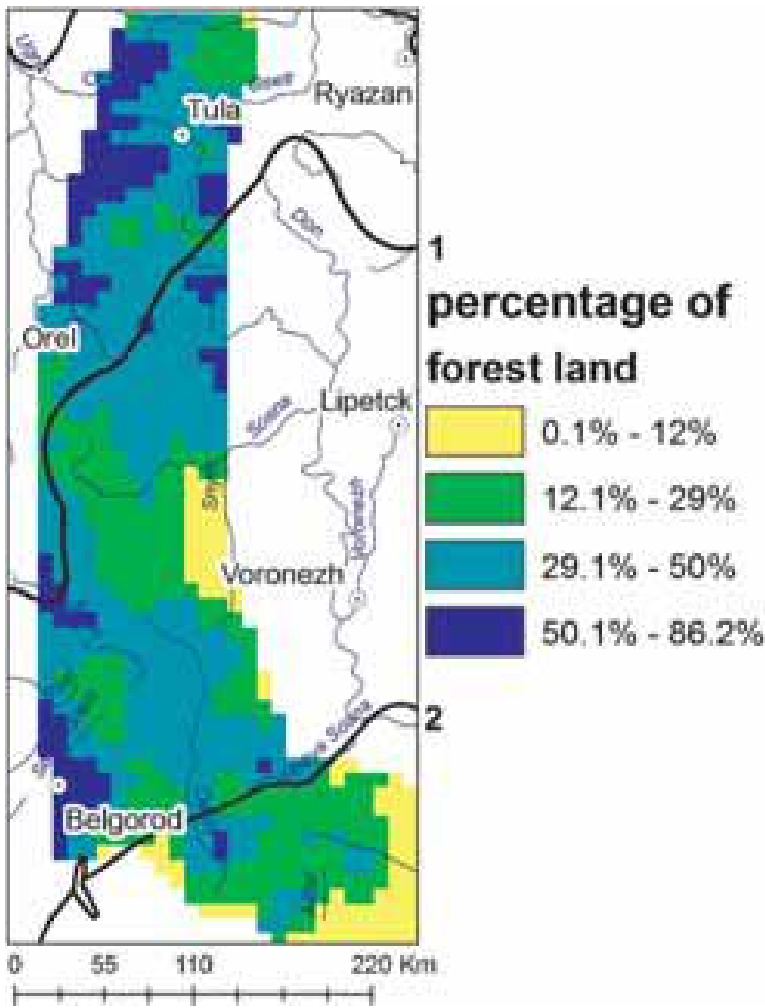

Fig. 8. The model of the forested land percentage along the transect (the XVI-XVII cc.).

broad-leaved forest and forest-steppe zones. The area of the forested land was $45 \%$ and $33 \%$ within the deciduous broadleaved forest zone and forest-steppe zone, respectively. The percentage of the forested land was low in the interfluve of the rivers Sosna and Snym and within the steppe zone.

\section{CONCLUSION}

The forests are distributed unevenly along the transect. The proportion of forests is lower in the north within the deciduous broad-leaved forest zone and in the contact

Table 2. Dynamics of the the abatis woodlands areas in the XVIII-XX cc.

\begin{tabular}{|l|c|c|c|}
\hline \multicolumn{1}{|c|}{ Region } & $\begin{array}{c}\text { Forested area } \\
\text { in 1770, km2 }\end{array}$ & $\begin{array}{c}\text { Forested area } \\
\text { in 2000, km2 }\end{array}$ & $\begin{array}{c}\text { Preserved } \\
\text { forested area, \% }\end{array}$ \\
\hline Tula abatis & 711.4 & 472.5 & 66.4 \\
Regions to the north from Tula abatis & 673 & 365.3 & 54.3 \\
South Tula abatis & 28 & 3.2 & 11.4 \\
Belgorod abatis in the Oskol region & 480.3 & 108.6 & 22.6 \\
Belgorod abatis, protected during the last 220 yrs. & 1186 & 620.8 & 54.3 \\
Belgorod abatis, not protected during the last 220 yrs & 237.3 & 23.1 & 9.7 \\
\hline
\end{tabular}


belt between the forest-steppe and steppe zones. Such forest distribution has not changed during the last 220 years and is mostly connected with different types of human impact. The forest protection for military purposes and afforestation promoted the high share of the forested land in the south of the transect. The average decrease of the forested land area was 5-6\% during the last 220 years. Within the deciduous broad-leaved forest zone, the forests were cut from the XVIII to the XIX cc., then, the percentage of the forested land increased somewhat. Within the forest-steppe and steppe zones, the forested area decreased during the last 220 years; most intensely forests were cut during the last 100 years in the contact belt between forest-steppe and steppe, where the former abatis woodlands were cut. Forest regeneration took place in the north of the Upland. New forests appeared mainly in ravines. Using the data of the abatis woodlands change since the end of the XVIII c., we modeled the forested land distribution in the XIXc.

\section{REFERENCES}

1. Arhipova, M.V., Zamesova, E.Ju. (2006). Botanical and geographical characteristics of the river Yazvitsy basin // Ecosystems of coniferous broad-leaved forests in the south of Moscow region. Collection of scientific works, Moscow. - P. 20-50.

2. Bartalev, S.A., Egorov, V.A., Ershov, D.V., Isaev, A.S., Lupjan E.A., Plotnikov, D.E., Uvarov, I.A. (2011). Satellite mapping of vegetation of Russia according to spectroradiometer MODIS data // Modern problems of the Earth remote sensing from space. Vol. 8, No 4. - P. 285-302.

3. Belevancev, V.G. (2012). Percentage of forest land and river network in the central Russian Belogor'e in 1780, 1880, and 1980 // Modern problems of science and education. No 6. www.science-education.ru/106-7750.

4. Chendev, Ju.G. (2008). Evolution of the Central Russian Upland forest-steppe soils in the Holocene. Moscow: GEOS. -212 p.

5. Jakovlev, A. The abatis line of Moscow state in the $17^{\text {th }}$ century: Story from the defense history of Moscow state south boundaries. M.: printing of I. Lissnera D. Sobko. IX. - 312 p.

6. Kuksa, I.V. (1993). A study of the forest distribution dynamics by satellite images and old maps // Synopsis of a thesis for the PhD degree of geographical sciences. Moscow. - 26 p.

7. Ogureeva, G.N. (ed.). (1999). Zones and altitudinal zonality types of vegetation of Russia and adjacent territories. Scale 1: 8 million. Explanation text and legend of the map. Moscow, Moscow State University press. - 64 p.

8. Plans-atlases of the counties of Tula, Orel, Kursk and Voronezh regions (1780). M 1:84000. RSAAA. Surveying storage. Fund 1356.

9. Strel'bitskii, I.A. (ed.). (1868-1887). A special map of European Russia. St. Petersburg: Military Topographical Department of General Staff press.

10. Spiridonov, A.I. (1978) Geomorphology of the USSR European part. Moscow: Higher School publishers. - $335 \mathrm{p}$. 
11. Tsvetkov, M.A. (1957). The change of forested land percentage of European Russia since the end of the XVII century to 1914. Moscow: Academy of Sciences of the USSR publishers. -213 p.

12. Zagorovskij, V.P. (1969). Belgorod abatis. - Voronezh: Voronezh University press. - 304 p.

13. Zagorovskij, V.P. (1980). Izjumskaja abatis. - Voronezh:Voronezh University press. - 200 p.

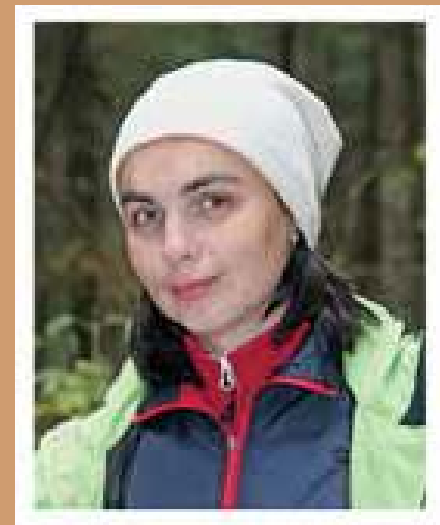

Maria V. Arkhipova graduated from the Moscow State University, Department of Biogeography, in 2001. At present, she is Research Associate at Sergeev Institute of Environmental Geoscience RAS (IEG RAS), Laboratory of Remote Sensing Methods for Geoenvironmental Monitoring. Her main scientific interests include botanical geography with the focus on problems related to forest science and remote sensing methods. She is the author of 15 scientific publications. 